\title{
THE EVOLUTION OF CONFLICT AS A BEHAVIOR PROCESS WITHIN GLOBAL ORGANIZATIONAL COMMUNICATION MANAGEMENT
}

\author{
Todăriţă Elida-Tomiţa ${ }^{1}$
}

\begin{abstract}
Nowadays, organizations are designed so that it can carry out their various activities necessary to face the uncertainty surrounding each of them. The consequences of these actions are reflected in differences between departments and a greater potential for the development and manifestation of conflict. When differentiation is coupled to a great extent with interdependence, the potential for conflict increases significantly. Also, always be considered in settling conflicts that often occur spontaneously but the most important thing in an organization is to avoid any activity or intentions which is to generate a possible conflict. In this paper, will present the theoretical aspects regarding the conflict, classification, patterns of events and also the tactics and strategies used to manage conflicts that may arise within an organization. In the end, will be dotted and conclusions regarding this approach..
\end{abstract}

Key words: conflict, conflict resolution, conflict in the organization, conflict management.

JEL codes: $M 12$

\section{Theoretical definition of conflict}

One was a conflict origin as inferred from the definition of intentional interference in the interests of individuals or groups other individuals or groups.

Conflict is the interference of an agent's or a group's intentions in the efforts of reaching certain objectives by another individual or group. It is supposed that the two parts involved have incompatible objectives, so that reaching the objective by one of the parts determines the impossibility of reaching the other implicated person. Conflict may therefore become a strategy to reach the superior objectives through the interference with the progress registered by the other parties.

The term conflict comes from the Latin word "conflictus" and it means, "hitting together with force" this thing meaning "disagreements and tensions between the members of the group, interaction in speech, emotions and affection". T.K. Gamble and M. Gamble (1993) define conflict as a positive variable, meaning that "besides all perspectives, conflict is a natural consequence of diversity".

The Explanatory Dictionary of the Romanian Language defines conflict as: misunderstanding, contradiction of interests, disagreement, antagonism, dispute, quarrel, (violent) discussion. Verb. To get into conflict (with somebody) $=$ to quarrel (with someone). 2 . Contradiction in ideas, the interests or feelings of different characters, which determines the development of the action in an epic or dramatic work.

Moreover, conflict is a process between two or more persons (groups, organizations, states) when they have different opinions, different objectives, needs and values and they fight on limited resources that could be used in order to solve the problems they are dealing with.

\footnotetext{
${ }^{1}$ Romanian-German University of Sibiu, Calea Dumbrăvii, Nr. 28-32, e-mail: elida_todarita@yahoo.com
} 
Conflict is a new form of opposition focused on the adversaries, based on the incompatibility of purposes, intentions and values of the opponent parties.

The following definition of conflict is accepted in the specialized literature: conflict represents a series of affective estates of individuals such as restlessness, hostility, resistance, open aggression, as well as all types of opposition and antagonistic interaction, including competition.

Conflicts might have negative and positive aspects. After a study conducted by the American Association of Management it has been concluded that managers in the upper and middle levels take approximately two hours of their time to solve certain conflict situations. Due to this fact, increasingly more specialists believe that solving the conflict is as important as the other activities of the management. Conflict is also a process of opposition and confrontation that might appear between different individuals and groups when each of them looks after his own interests. A conflict between groups might show up only when they are different among them but depend on each other.

\section{The classification of conflicts}

I. From the point of view of their essence, conflicts can be:

1. essential (of substance) generated by the existence of some different objectives;

2. emotional, generated by emotional states which aim interpersonal relationships;

3. manipulation conflicts;

4. pseudo-conflicts.

II. From the point of view of the subjects which are in conflict, the following categories of conflict can exist:

1. the internal individual conflict;

2. the conflict between individuals of the same group;

3. of different groups;

4. of different organizations;

5. the conflict between individuals and groups;

6. the inter-groups conflict;

7. the conflict between organizations.

III. From the point of view of their general effects:

1. destructive;

2. beneficial.

In order to simplify the managerial analysis, the process of conflict can be divided in five sequences, namely:

1. the latent conflict;

2. the perceived conflict;

3. the considerate conflict;

4. the manifest conflict;

5. the final conflict. evolution.

Conflicts may also be spontaneous, acute and comical, according to the duration and

1. Destructive or out of control, which could not be solved at the right time, either because the parties did not show a real interest, or because problems have been so serious that a solution accepted by the ones involved has not been reached;

2. Beneficial: these conflicts make individuals and organizations to become more creative and productive. The conflict prevents the individuals' and organizations' situations of stagnation, eliminates tensions and facilitates changes.

The characteristics of beneficial and destructive conflicts shall be exemplified in table no. 1 . 
The characteristics of beneficial and destructive conflicts

\begin{tabular}{|c|c|}
\hline Destructive conflict & Beneficial conflict \\
\hline It is generated by errors. & It is generated by multiple causes. \\
\hline It is out of control, not being solved at the right moment. & $\begin{array}{l}\text { It can be maintained at an honourable } \\
\text { level. }\end{array}$ \\
\hline $\begin{array}{l}\text { Problems have been serious that an accepted solution } \\
\text { could not have been reached. }\end{array}$ & $\begin{array}{l}\text { A solution accepted by the ones involved } \\
\text { can be reached. }\end{array}$ \\
\hline $\begin{array}{l}\text { Communication between competitors becomes } \\
\text { troublesome and not trustworthy. }\end{array}$ & $\begin{array}{l}\text { Communication between competitors } \\
\text { becomes intense and trustworthy. }\end{array}$ \\
\hline $\begin{array}{l}\text { The ability of each part to notice and answer the } \\
\text { intentions of the other part is seriously affected. }\end{array}$ & $\begin{array}{l}\text { Each part notices and answers the } \\
\text { intentions of the other. }\end{array}$ \\
\hline \multicolumn{2}{|c|}{ Means of obtaining certain advantages } \\
\hline Actions in force, reality distortion, garbled information & Open competition \\
\hline \multicolumn{2}{|l|}{ Evolution } \\
\hline $\begin{array}{l}\text { The more the conflict increases and the stakes become } \\
\text { more important, the lower the chances to reach a solution } \\
\text { are. }\end{array}$ & $\begin{array}{l}\text { The more the conflict increases and the } \\
\text { stakes become more important, the more } \\
\text { the efforts and investments increase with } \\
\text { chances to solve the problems. }\end{array}$ \\
\hline \multicolumn{2}{|l|}{ Influence factors } \\
\hline The importance and number of dispute moments & $\begin{array}{l}\text { The importance and number of } \\
\text { competition points }\end{array}$ \\
\hline The number and importance of participants & $\begin{array}{l}\text { The number and importance of } \\
\text { participants }\end{array}$ \\
\hline The expenses that participants are willing to bear & $\begin{array}{l}\text { The expenses that participants are willing } \\
\text { to bear }\end{array}$ \\
\hline $\begin{array}{l}\text { The number of constraints left behind during the } \\
\text { confrontation }\end{array}$ & $\begin{array}{l}\text { The number of constraints left behind } \\
\text { during the confrontation }\end{array}$ \\
\hline \multicolumn{2}{|l|}{ Effects } \\
\hline Negative effects on the objectives' achievement & $\begin{array}{l}\text { Individuals and organizations become } \\
\text { more creative and more productive }\end{array}$ \\
\hline $\begin{array}{l}\text { Personal and organizational resources wear out in } \\
\text { conditions of hostility and contempt, existing a } \\
\text { permanent state of dissatisfaction }\end{array}$ & $\begin{array}{l}\text { It allows a better distribution of } \\
\text { resources, it eliminates tensions and it } \\
\text { facilitates changes. }\end{array}$ \\
\hline The shutting down of the factories & $\begin{array}{l}\text { It provides the employees' motivation by } \\
\text { leading towards a creative behaviour }\end{array}$ \\
\hline - & $\begin{array}{l}\text { It increases the employees' cohesion, } \\
\text { level of organization and loyalty. }\end{array}$ \\
\hline
\end{tabular}

\section{Types of conflicts}

Thomas believes that the types of conflict describe either the process, or the structure of a conflict situation. There are various types of theoretical types of conflict.

One of the types would be the procedural type, elaborated by Pondy which starts from the premise that the only way to understand conflict is to perceive it as a dynamic, rather than stable or static process. Therefore, there is:

1. Latent conflict: determined by the consequences of certain previous conflict episodes. For example we mention the insufficient resources, the desire to have more autonomy, the differences 
between personal and organizational goals. This type of conflict is often influenced by the external environment.

2. Understood conflict: it comes along together with becoming aware of the existence of some latent conditions. The divergent purposes and objectives do not create conflict as long as this is not obvious. Conflict remains in a latent state, the ones involved not giving it a significant importance. Then it turns into conflict felt only when we turn our attention towards it. Although there can be more conflicts than we can handle, this type of conflict does not necessarily become a felt conflict.

3. The manifest conflict: it is expressed by behaviour, the most often reactions being apathy, dramatic attitude, open hostility or aggressiveness.

If a conflict has been solved, the parties involved can move towards cooperation. Otherwise, the conflict grows in intensity and may include issues that have not been initially involved.

The most often encountered sources of conflict are:

1. The lack of communication: most of the times it is the main source of conflict. In this situation, the only way to solve conflict is cooperation, which allows each part to find out the other part's position and arguments, if the ones involved in the conflict wish to cooperate for finding the most acceptable solution. The change of information allows each part to have access to the other part's arguments and knowledge, distrust, confusion and misunderstanding being therefore much easily diminished;

2. Disagreement: it mostly aims ethical aspects, the ways in which power should be exercised, taking into consideration the moral integrity and honesty;

3. The limited resources: if this happens within the organization, the development of certain structural elements affects the other departments' possibilities. The relations between the departments of an organization are determined by the reactions to necessities;

4. The social status: it represents another source of structural conflict which increases some groups' chances to gain it, to be more specific, we are talking about the relations between the production and management departments of the companies where there are interactions and feelings that define a state of conflict.

\section{The way conflicts manifest}

In this case, conflicts may take the shape of conflicts of interest, the shape of complaints, of unfair labour practices but also of conflicts of recognition.

However, the first type of event occurs when negotiation between unions and employers can not be solved, an understanding can not be reached therefore requiring the intervention of a mediator.

The second way of manifestation is the complaint and it concerns the employees' protests due to some treatments which are considered unfair or the violation of certain rights. Since there are specific rules in this respect, this type of conflict can theoretically be solved relatively fast.

Unfair practices, namely the immoral practices or we can even state the breach of ethics at the work place are always solved by legislation, the presumption being that a right has been illegally exercised.

\section{The process and manifestation stages of conflict}

The existence of a generator source of conflict which describes a latent state, the perception in a different way of conflict which shows a perceived conflict, the explicit appearance of the state's of conflict features, which show a felt conflict, the open action meant to solve the conflict, which shows a manifested state and the appearance of conflict's consequences could be considered important stages in the appearance and manifestation of conflicts.

All the above mentioned stages prove the existence of an emotional element; the ones involved beginning to feel hostility and tension between them. Now, the felt conflict has a personalized character, each individual having his own reaction. Therefore, the activity begins to be 
less productive, unproductive rumours and actions making their presence felt. Under these circumstances, one way of diminishing pressure is the meetings.

\section{Tactics and strategies to manage conflict}

The exact definition of the quarrel, narrowing the dispute ground and widening the area of possibilities to solve problems are preliminary actions that might lead to the increase of chances to succeed in solving the conflicts.

In order to choose the best strategy to manage conflict a number of factors have to be had in view, such as: the conflict's seriousness, the question of time (if it needs to be solved urgently or not), the result which is considered adequate, the manager's power, the personal preferences, the strengths and weaknesses he shows in handling the conflict.

Thomas identifies five ways to solve conflicts:

Table no.2

Ways to solve conflicts

\begin{tabular}{|c|c|}
\hline Ways & Contextual situations \\
\hline Avoidance & $\begin{array}{l}\text { The problem is not important or other issues have become more pressing; } \\
\text { There is no chance to satisfy your interests; } \\
\text { The outbreak of a conflict is more plausible than solving the problem; } \\
\text { Letting people calm down and making a perspective on how things go; } \\
\text { The necessity of additional information; } \\
\text { Others can solve the conflict better; } \\
\text { Problems seem to be essential or symptomatic. }\end{array}$ \\
\hline Collaboration & $\begin{array}{l}\text { Finding some solutions for interests of major importance; } \\
\text { When its objective is to learn; } \\
\text { Combining contradictory opinions; } \\
\text { Gaining everyone's adhesion by considering various interests and } \\
\text { accomplishing a general agreement. }\end{array}$ \\
\hline Competition & $\begin{array}{l}\text { When decisional rapidity is of vital importance; } \\
\text { In important problems, when unpopular actions need to be implemented; } \\
\text { In vital issues for the company when managers are convinced that their } \\
\text { opinion is correct; } \\
\text { Against the ones that take advantage of the tolerant attitude. }\end{array}$ \\
\hline Compromise & $\begin{array}{l}\text { The objectives are important but the risk of setting off a new conflict is too } \\
\text { high; } \\
\text { The equally powerful opponents are determined to use ideas that would } \\
\text { mutually exclude each other; } \\
\text { For the temporary achievement of a balance; } \\
\text { To ensure an "honourable" retreat when collaboration or competition can } \\
\text { not lead to a positive result from the point of view of satisfying its own } \\
\text { interests. }\end{array}$ \\
\hline Accommodation & $\begin{array}{l}\text { When you reach the conclusion that your own arguments are not correct; } \\
\text { In order to allow for a better solution to be applied; } \\
\text { In order to get social credit for the perspective of the appearance of future, } \\
\text { more important problems; } \\
\text { In order to minimize losses; } \\
\text { When the situation is out of control; } \\
\text { When harmony and stability are essential. }\end{array}$ \\
\hline
\end{tabular}

Source: Rout Eirene Leela, Omiko Nelson, 2007. Corporate Conflict Management: concepts and skills, Prentice-Hall of India, New Delhi, pp. 82-89 

conflict:

Other researchers in the field claim that the following strategies can be used to manage

1. Ignoring the conflict: if there is the danger of a destructive conflict, the manager's inability to deal with it may be interpreted as a way to avoid managerial responsibilities;

2. Tolerating the conflict: if the conflict is not very strong and it is considered to increase the organizational performances, it can be tolerated, the manager's responsibility being to permanently keep under observation the conflict so that it does not become destructive.

Also with the purpose of solving the conflicts from the perspective of the manager's action, the following approaches can still be encountered in the specialized literature:

1. The retreat: the manager does not present interest for solving the conflict and he prefers not to get involved. This is a dangerous strategy because it may give rise to certain communication blockings both horizontally and vertically within the organization;

2. The straightening of things out: it is the strategy used by those managers who seek the approval of the ones around to make sure that the organizational objectives are met. Therefore, he will try to please everybody;

3. Forcing: it is the manager's approach who, under these circumstances, wishes, at any price, to reach the productivity objectives and will resort to coercion, overusing the power he was invested with;

4. The compromise: this is among the manager's attitudes, being among the second and the third type of strategy, most often being reached through negotiation;

5. The confrontation: the only approach that can lead to the final settlement of the conflict, taking into consideration both the need for productivity and the inter-human cooperation.

As far as the action to calm down organizational conflicts is concerned, this can be preventive or it may occur after the conflict has started.

Therefore, different types of intervention of the conflict will be shown below, delimitated according to different criteria:

I. Reducing or eliminating conflict:

1. Short-term strategies:

a) The arbitration by an arbitration commission whose decision is final;

b) the persuasion: the attempt to convince one part to give up its position;

c) the constraint;

d) ,the buying”.

2. Long-term strategies: separation, mediation, appeal, confrontation.

According to another classification of the types of intervention of conflicts, there are three main types of strategies:

a) Negotiation: the communication process with the purpose of reaching an agreement between the two parts in conflict by reducing the differences of opinion;

b) Mediation: it promotes communication for reaching a compromise by explaining and interpreting the points of view of the two parts. It also supposes the existence of a third part, which arranges communication; authority.

c) Arbitration: it supposes the existence of a third specialized person who has decision

\section{Solving the conflict}

Solving the conflict is achieved by:

1. Establishing common objectives: if a major source of conflict is represented by pursuing different objectives, the manager has to try to suggest objectives equally accepted by the groups that are in conflict. What is coming next is a restructuring.

2. Improving communication processes: the communication boundaries between the manager and the other members of the organization or only between members are few. 
Communication between the members of the organization has to be stimulated by intensifying informational changes between departments.

3. Integrative negotiation: the essence of this process is that none of the parts does not have to give up the aspects it considers vital. People must be encouraged to find a creative solution instead of compromise.

\section{Conflict prevention}

Conflict prevention can be achieved through quality dialogue within the organization. This requires an active participation at the work place and also in the actual human relations and their financial incentive.

The manager, in order to prevent a destructive conflict has to do this:

1. To ask for peoples' opinions and listen to them carefully;

2. To address criticism in a constructive manner;

3. To not start from the premise that they know what the others feel about certain important subjects;

4. Before taking the decision that might affect the activity of the other, he should be consulted or be stimulated to take part in their elaboration;

5 . To encourage people or groups who get into constructive disputes;

6. To try to find ways to allow both parts of a conflict to leave the ground with a certain dignity.

IV. Conclusions regarding the conflict's types of intervention

After analysing the different types of conflict, as well as the evolution, the forms and types of conflict management, we can state that most of the people consider conflicts as destructive quarrels, from which some win to the disadvantage of others. The conflict has to be considered as an inevitable aspect of the organization's life, and it may give rise to the motivation of solving the problems that would otherwise go unnoticeable, therefore reaching a creative behaviour. Within an organization, it is necessary for managers to have more possibilities of constructive solving of the conflict situations.

\section{Conclusions}

The conflict management requires first to establish and choose the conflict dimension desired within the organization. Avoiding or stimulating conflicts may be achieved by using the three structural causes according to the objective had in view. Then it can be chosen between collaboration or negotiation, depending on how the parts trust each other and decide to use together the information they hold.

Conflicts arise when coordination mechanisms are strained and fail to achieve the necessary degree of cooperation organization.

\section{Acknowledgements}

Researches carried out within the framework of the project POSDRU/6/1.5/S/26, co financed from the Social European Fund by means of the Sectorial Operational Fund Programme "The Development of Human Resources” 2007-2013.

\section{References}

1. Bălănică, Silviu, 2003. Comunicare în afaceri, Editura ASE, Bucureşti, p. 2.

2. Maruşca, Laura, 2010. Comunicare şi conflict. Managementul comunicării în soluţionarea amiabilă a conflictelor, Editura Tritonic, Bucureşti, pp. 10-15.

3. Rout, E., Leela, Omiko, Nelson, 2007. Corporate Conflict Management: concepts and skills, Prentice-Hall of India, New Delhi, pp. 82-89.

4. Shapiro, Daniel, 2005. Conflict and communication: a guide through the labyrinth of conflict management, Idea Press, New York, pp. 114-140. 
5. Stephen, W., Littlejohn, Karen, A., Foss, 2009. Encyclopedia of Communication Theory, Sage Publications, California, pp. 164-167. 